\title{
Treatment Options for Idiopathic Restless Legs Syndrome
}

\author{
Félix Javier Jiménez-Jiménez, ${ }^{1}$ Hortensia Alonso-Navarro, ${ }^{2}$ Elena García-Martín ${ }^{3}$ and José AG Agúndez ${ }^{4}$
}

1. Chairman of the Section of Neurology; Professor of Neurology, Hospital Universitario del Sureste, Arganda del Rey, Madrid, Spain; 2. Consultant Neurologist, Section of Neurology, Hospital Universitario del Sureste, Arganda del Rey, Madrid, Spain; 3. Professor of Pharmacology, Universidad de Extremadura,

\author{
Cáceres, Spain; 4. Full Professor of Pharmacology, Universidad de Extremadura, Cáceres, Spain
}

\begin{abstract}
The emergence of new effective therapies for idiopathic restless legs syndrome (iRLS) or Willis-Ekbom disease (WED) during the last 15 years resulted in an exponential increase of reports regarding this syndrome and, especially, treatment options. In this review, we summarise the main findings related to neuropharmacological aspects and non-pharmacological therapies of idiopathic RLS (iRLS). As was previously reported in several guidelines, dopamine agonists (fundamentally nonergotic derivatives), gabapentin and pregabalin should be considered as first-line therapies, as well as opiates as an alternative drug group. Preliminary results suggest that several non-pharmacological therapies should be promising as alternatives or adjuvants to drug treatments.
\end{abstract}

\section{Keywords}

Restless legs syndrome, therapy, dopamine agonists, gabapentin, pregabalin, opiates, non-pharmacological therapies

\begin{abstract}
Disclosures: Félix Javier Jiménez-Jiménez, Hortensia Alonso-Navarro, Elena García-Martín and José AG Agúndez have no conflicts of interest to declare. Research at authors' laboratories is financed by grants PS09/00943, PS09/00469, P112/00241, P112/00324 and RETICS RD12/0013/0002 from Fondo de Investigación Sanitaria, Instituto de Salud Carlos III, Spain, Innovation and GR10068 from Junta de Extremadura, Spain. Financed in part by FEDER funds from the European Union. No funding was received for the publication of this article.

Open Access: This article is published under the Creative Commons Attribution Noncommercial License, which permits any non-commercial use, distribution, adaptation and reproduction provided the original author(s) and source are given appropriate credit.

Received: 27 February 2015 Accepted: 15 April 2015 Citation: European Neurological Review, 2015;10(1):45-55 DOI: 10.17925/ENR.2015.10.01.45

Correspondence: Félix Javier Jiménez-Jiménez, C/Marroquina 14, 3 B, E-28030 Madrid, Spain. E: fjavier.jimenez@salud.madrid.org; felix.jimenez@sen.es Supplementary Material: Supplementary material to this article is available online at http://www.touchneurology.com/
\end{abstract}

Restless legs syndrome (RLS), or Willis-Ekbom disease (WED), is a sensorimotor disorder having well-known standardised diagnostic criteria' that have been revised recently by the International Restless Legs Syndrome Study Group. ${ }^{2}$ The genetic basis of RLS has not been definitively established, ${ }^{3}$ but the most important biochemical findings are dopaminergic dysfunction and iron deficiency. ${ }^{4}$

The interest for RLS is relatively recent, with the number of publications on this issue growing exponentially. A current PubMed search shows 3,601 papers on this topic from 1966 to today, 2,967 published from 2000 to 2015 (541 from 2000 to 2004; 1,045 from 2005 to 2009; 1,381 from 2010 to February 24, 2015). Many of these reports are related to the development of efficacious drugs - especially dopamine agonists, the most effective for the treatment of RLS/WED.

In this review, we summarise the main findings related to neuropharmacological aspects of idiopathic RLS (iRLS) and to nonpharmacological therapies.

\section{Search Strategy}

References for this review were identified by searching PubMed from 1966 until February 25, 2015. The term "restless legs syndrome" was crossed with "pharmacology", "neuropharmacology", "treatment" and "therapy". This search retrieved 2,192 references, which were individually examined, with related references of interest $(n=274)$ selected. According to this search, drugs essayed for the treatment of iRLS are summarised in Table 1.

\section{Drugs Enhancing Dopaminergic Neurotransmission Levodopa}

The results of studies on the efficacy of levodopa (the precursor of dopamine) in the treatment of iRLS are summarised in supplementary Table 1. All these studies, independent of their design, showed significant improvement of RLS symptoms and/or periodic limb movements (PLMS). ${ }^{5-17}$ Some of them mentioned the presence of a rebound phenomenon in the last part of the sleep time when using regularrelease levodopa, ${ }^{7,14-16}$ which was improved by the use of sustainedrelease levodopa alone ${ }^{15,16}$ or combined with regular-release levodopa. ${ }^{14}$

Stiasny-Kolster et al. ${ }^{18}$ validated the so-called "levodopa test" for the diagnosis of RLS. This consisted of the application of a single dose of benserazide/levodopa 25/100 mg with a subsequent 2-hour period of observation, considering as "positive" a $50 \%$ improvement in "symptoms in the legs" (sensitivity $80 \%$; specificity $100 \%$ ) and "urge to move the legs" (sensitivity $88 \%$; specificity $100 \%$ ) in 15-minute intervals.

Guilleminault et al..$^{19}$ investigated the rebound phenomenon in $20 \mathrm{RLS}$ patients treated with a bedtime dose of controlled-release carbidopa/ levodopa 25/100 mg. Even though at 4 to 7 weeks none of the patients exhibited subjective RLS symptoms, and PLMS reduced by $80 \%$ after $11 \pm 2$ months of follow-up, seven subjects reported the re-emergence of disturbing RLS symptoms between 8:00 pm and 11:00 pm. This rebound phenomenon disappeared in four patients after drug withdrawal (with reappearance of the RLS symptoms) and reappeared after its 


\section{Table 1: Classification of Drugs Assayed for Treatment of Restless Legs Syndrome}

A) Drugs enhancing dopaminergic transmission
1. Levodopa
2. Nonergotic dopamine agonists: ropinirole, pramipexole, rotigotine,
talipexole, piribedil, apomorphine
3. Ergotic dopamine agonists: pergolide, cabergoline, bromocriptine, alpha-
dihydroergocryptine, terguride, lisuride
4. Amantadine (inhibitor of dopamine uptake, mild action as $\mathrm{D}_{2}$ agonist,
inhibitor of N-methyl-D-aspartate receptors)
5. Aripiprazole (partial agonist of $\mathrm{D}_{2}$ receptor)
6. Monoamine oxidase B inhibitors (selegiline, rasagiline)
7. Bupropion (inhibitor of dopamine and noradrenalin uptake)
B) Antiepileptic drugs
1. Gabapentin
2. Pregabalin
3. Valproate
4. Other (carbamazepine, topiramate, lamotrigine, levetiracetam,
E) Iron (oral or intravenous)
F) Botulinum toxin
G) Other drugs (described in the text)
1. Morate drugs:
1. Morphine
2. Tramadol
3. Oxycodone
4. Methadone
D) Benzodiazepines
1. Clonazepam

reintroduction. Rebound phenomenon was adequately controlled in the seven patients after placing them on two doses of controlled-release carbidopa/levodopa 25/100 mg (at night and in the morning).

The other important long-term side effect of levodopa (and dopamine agonists) is the augmentation phenomenon, defined as a loss of circadian recurrence with progressively earlier daily onset and increase in the duration, intensity and distribution of symptoms. ${ }^{20}$ This complication has been found in up to $82 \%$ of patients treated with levodopa, mainly in those having more severe symptoms and in those using higher doses of this drug. ${ }^{21}$ Vetrugno et al. ${ }^{22}$ showed a temporal relation between low plasma levodopa levels and signs of augmentation in a patient, with improvement of RLS symptoms 75 minutes after oral levodopa administration and reappearance of these symptoms after 3 hours, coinciding with rapid rise and fall of plasma levodopa concentrations.

García-Borreguero et al. ${ }^{23}$ studied circadian changes in dopaminergic function by means of measurement of responses of growth hormone (GH) and prolactin (PRL) to two acute administrations of carbidopa/ levodopa 50/200 mg (one at $11 \mathrm{am}$ and other at $11 \mathrm{pm}$ ) in $12 \mathrm{iRLS}$ patients and 12 healthy controls. Though basal plasma GH and PRL levels were similar in both groups, nocturnal administration of levodopa induced a more pronounced inhibition of PRL release and an increase in GH secretion, PRL plasma levels being correlated with the PLM index in polysomnography. This group determined dim light melatonin onset (DLMO), a marker of circadian phase, in eight previously untreated iRLS patients before and after a 3-week open-label treatment with carbidopa/ levodopa 100/400 mg and showed a significant anticipation of DLMO after levodopa treatment. ${ }^{24}$ These findings suggest increased circadian variations in dopaminergic function in IRLS patients.

Two systematic reviews, including nine eligible trials, concluded that the short-term treatment of RLS and PLMs with levodopa showed efficacy and safety; however, the assessment of the usefulness of long-term treatment and the development of the augmentation phenomenon has not been investigated sufficiently. ${ }^{25,26}$

Shariff ${ }^{27}$ reported increased duration of the action of carbidopa/ levodopa induced by entacapone (a peripheral inhibitor of catecholortho-methyl-transferase [COMT]) in a patient who had RLS. Afterwards, Polo et al..$^{28}$ confirmed that the association of entacapone to carbidopa/ levodopa was useful to prolong symptom control in a randomised, double-blind, crossover study with polysomnography.

\section{Dopamine Agonists}

The studies of ropinirole, ${ }^{29-41}$ pramipexole, ${ }^{42-73}$ rotigotine, ${ }^{74-85}$ pergolide ${ }^{86-94}$ and cabergoline, ${ }^{95-101}$ respectively, in the treatment of iRLS are summarised by supplementary Tables 2, 3, 4, 5, and 6. All these studies comparing dopamine agonists with placebo showed a significant improvement in the severity of RLS (assessed with several scales, being the most frequently used the International RLS Study Group Scale), in the IRLS frequency of "responder" rates (improvement in $>50 \%$ ), in the Clinical Global Impression Improvement (CGI-I) and Patient Global Impression Improvement (PGI-I), in the quality of life (QoL) and in polysomnographic (PSG) measurements.

The efficacy, safety and tolerability of sumanirole (a highly selective D2 agonist) has been assessed in a double-blind, placebo-controlled, randomised, parallel-group, dose-response study involving 270 patients with iRLS randomised to sumanirole $0.5,1.0,2.0,4.0 \mathrm{mg}$ or placebo. ${ }^{102}$ Even though this drug was well tolerated, only the dose of sumanirole 4.0 showed improvement in the International Restless Legs Scale-10 (IRLS10) compared with placebo or with lower doses of sumanirole. PSG variables, especially the periodic leg movements index (PLMI), improved in a dose-related manner during sleep. ${ }^{102}$

Other dopamine agonists, including bromocriptine, ${ }^{103}$ talipexole, ${ }^{104}$ amantadine, $^{105}$ alpha-dihydroergocryptine, ${ }^{106}$ piribedil, ${ }^{107}$ terguride, ${ }^{108}$ aripiprazole, ${ }^{109}$ apomorphine (subcutaneous) $)^{10-112}$ and lisuride (transdermal) ${ }^{113,114}$ have shown efficacy in the treatment of RLS, most of them in open-label studies having a low sample size.

Two studies showed higher efficacy of pergolide ${ }^{86}$ and cabergoline ${ }^{101}$ in comparison with levodopa. In particular, the study with cabergoline was of higher duration, involved an important number of patients and found less frequent augmentation for cabergoline than for levodopa. ${ }^{101}$ Improvement of RLS obtained with pramipexole did not differ significantly from that obtained with levodopa ${ }^{60}$ or with ropinirole ${ }^{67}$ in two comparative studies.

Several systematic reviews and/or meta-analysis on the efficacy or dopamine agonists in the short-term treatment of RLS have been reported to date:

(a) A systematic review and meta-analysis of six randomised, doubleblind, placebo-controlled, parallel-group trials involving 1,679 RLS patients (835 receiving immediate-release ropinirole and 844 placebo) showed evidence that ropinirole improved sleep quality and adequacy, and decreased daytime somnolence, in RLS patients. ${ }^{115}$ 
(b) An evidence-based review showed a clear evidence of the effectiveness of pramipexole in studies published up to 2004, both in reduction of the leg movements associated with RLS and in improvements in both the International Restless Legs Syndrome Rating Scale (IRLSSGRS) and in the Clinical Global Impression (CGI) scores, with moderate evidence of improving sleep quality. ${ }^{116}$

(c) A meta-analysis of studies published until 2013 showed a favourable effect of pramipexole in comparison with placebo in IRLSSGRS and sleep quality ( $p<0.00001$ each), with nausea (RR 1.82-3.95; $p<0.001$ ) and fatigue (RR 1.14-2.93; $\mathrm{p}=0.013$ ) the most common adverse effects and, in general, good tolerance to pramipexole. ${ }^{117}$

(d) Quilici et al. ${ }^{118}$ reported data from a meta-analysis of studies on the efficacy and tolerability of pramipexole and ropinirole published up to 2008. Both dopamine agonists were significantly better than placebo in improving IRLSSGS scores and CGI-I scale; pramipexole showed a higher incidence of nausea than placebo; and ropinirole showed a higher incidence of nausea, vomiting, dizziness and somnolence than placebo. The indirect comparison of pramipexole and ropinirole showed significantly higher reduction in IRLSSGS score and higher improvement in CGI-I scale, as well as lower incidence of nausea, vomiting and dizziness for pramipexole.

(e) Bogan ${ }^{119}$ reviewed all clinical trials of rotigotine in RLS and concluded that this drug was efficacious in improving RLS symptoms and was generally well tolerated, with low risk of developing clinically significant augmentation.

(f) Several systematic reviews assessing the efficacy of dopamine agonists as a generic group concluded that these drugs showed moderate efficacy in short-term studies (up to 7 months) in improving the IRLSSGS score and CGI-I scores and in QoL scales scores, a higher frequency of IRLSSGS "response" (defined as a $>50 \%$ reduction in IRLSSGS score), ${ }^{120-125}$ a higher improvement in QoL scales scores ${ }^{120,122-126}$ and an important reduction in PLMI, ${ }^{20,122-125}$ though with a significantly higher frequency of adverse effects and likelihood of dropout than patients under placebo. ${ }^{120-122}$ Active controlled and long-term studies are scarce. ${ }^{122,123}$

Three studies analysed the results of long-term treatment of RLS ( 5 years or longer) with dopamine agonists:

(a) Ondo et al., ${ }^{127}$ in a 7-year longitudinal retrospective study, showed that efficacy of dopamine agonists was maintained across time but with a moderate significant increase in dose and presence of augmentation (usually modest) in $48 \%$ of patients, most of them having a positive family history of RLS and lack of neuropathy in nerve conduction studies.

(b) Silver et al., ${ }^{128}$ in a 10-year longitudinal retrospective study of RLS patients treated in a tertiary care centre with pramipexole or pergolide, found annual rates for discontinuing treatment of $9 \%$ for pramipexole and $8 \%$ for pergolide, with annual rates of augmentation of $7 \%$ for pramipexole and $5 \%$ for pergolide. Only $58 \%$ of patients under pramipexole and $35 \%$ under pergolide continued the treatment for more than 5 years.

(c) Data from a prospective open extension period of a preceding double-blind placebo-controlled trial with rotigotine ${ }^{80}$ are summarised in Supplementary Table 4.

The effect of controlled withdrawal of dopamine agonists has been studied for pramipexole by Trenkwalder et al. ${ }^{129}$ in 150 RLS patients who had responded to pramipexole (mean dose $0.50 \mathrm{mg}$ ) during at least 6 months and were randomised to receive placebo or to continue receiving pramipexole $0.125-0.75 \mathrm{mg} /$ day for 3 months. A total of $88.5 \%$ patients randomised to placebo versus $20.5 \%$ to pramipexole, worsened more often and more quickly in a CGI-I $(p<0.0001)$. Augmentation was not reported as side effect by any of these patients.

The response of RLS symptoms to ropinirole seems to be independent of age ${ }^{130}$ and serum ferritin levels. ${ }^{131}$ Both ropinirole ${ }^{132}$ and pramipexole ${ }^{65}$ improved depressive symptoms in RLS patients. Dopaminergic drugs can be related to pathological gambling (7\%) and increased sexual desire (5\%) in RLS patients. ${ }^{133}$

As previously commented, the augmentation phenomenon is an important long-term side effect of dopamine agonists. Several studies addressed the frequency of augmentation in patients under dopamine agonist treatment:

(a) Augmentation was present in $3.5 \%$ of RLS patients under ropinirole and in less than $1 \%$ of patients under placebo during the double-blind phase, as well as in $3 \%$ of RLS under ropinirole during the open-label phase, of a study involving 404 patients in a 26-week double-blind flexible-dose treatment with ropinirole or placebo, followed by an open-label phase involving 269 of these patients under ropinirole. ${ }^{134}$

(b) Ferini-Strambi i35 reported augmentation in $8.3 \%$ of 60 RLS patients under pramipexole therapy in an open-label clinical series, this side-effect being more frequent in patients who had secondary RLS (4/21) than in those who had iRLS (1/39). Augmentation was unrelated to severity of RLS or with doses of pramipexole. Silber et al. ${ }^{136}$ reported augmentation in $33 \%$ of 60 RLS patients, which increased to $48 \%$ in 50 patients with a long-term follow-up period under pramipexole. ${ }^{137}$ Finally, Winkelmann et al. ${ }^{138}$ reported augmentation in $32 \%$, and tolerance in $46 \%$, of 59 RLS patients treated with pramipexole.

(c) Beneš et al. ${ }^{139}$ retrospectively reviewed data from two doubleblind placebo-controlled 6-month trials involving 745 rotigotine and 214 placebo subjects, as well as from two open-label 1-year trials involving 620 rotigotine subjects looking for the frequency of augmentation according to the Max Planck diagnostic (MPD) criteria, ${ }^{140}$ which included usual time of RLS symptom onset each day, number of body parts having RLS symptoms, latency to symptoms at rest, severity of the symptoms when occurring and effects of dopaminergic medication on symptoms. They found that $8.2 \%$ of subjects (11 subjects under rotigotine and one under placebo) reporting clinically relevant augmentation in the double-blind trials and $9.7 \%$ (2.9\% having clinically relevant augmentation) fulfilled MPD criteria for augmentation.

(d) Allen et al. ${ }^{141}$ assessed the frequency of augmentation, using National Institutes of Health (NIH) guidelines, in a community sample of 266 patients who had RLS under long-term dopamine agonist therapy. A total of $20 \%$ of patients were classified as having definitive or probable augmentation, the main risk factors being the presence of most frequent RLS symptoms pretreatment, greater severity of RLS symptoms pre-treatment and longer treatment duration.

(e) Two studies that reported augmentation in $10.65 \%$ of $338^{142}$ and $11.7 \%$ of 162 RLS patients ${ }^{143}$ who had long-term dopaminergic therapy showed significantly lower serum ferritin levels in patients who had augmentation than in patients who did not experience this side effect. ${ }^{142,143}$ 
Studies using transcranial magnetic stimulation showed reduction in the short latency intracortical inhibition ${ }^{144}$ and shortening in the cortical silent period ${ }^{145}$ (both inhibitory phenomena) in RLS patients, reversed with cabergoline treatment. ${ }^{144,145}$ The amplitude of the motor evoked potential after a rest period was increased after pramipexole treatment, suggesting delayed facilitation. ${ }^{146}$

In the evaluation of results of clinical trials involving RLS patients, it is very important to consider the placebo responses. This issue has been addressed by De la Fuente-Fernández, ${ }^{147}$ who, after analysing two large multicentre trials on the efficacy of rotigotine in RLS, showed that in RLS trials dopaminergic pretreatment should condition the interpretation on the apparent effect of new dopaminergic drugs by decreasing the placebo effect in the placebo arm but not in the active treatment arm. Moreover, Fulda et al. ${ }^{148}$ reported a response rate for placebo of around $40 \%$ in a pooled study of 24 eligible trials of RLS treatments.

\section{Monoamine Oxidase B Inhibitors}

One open-label study described a significant improvement $(p<0.0005)$ of PLMI during sleep in a cohort of 31 RLS patients treated with selegiline, ${ }^{149}$ and an anecdotal report described improvement of RLS symptoms in a patient with an 8-year history of RLS who developed Parkinson disease 7 years later. ${ }^{150}$

\section{Bupropion}

This antidepressant, which inhibits dopamine and noradrenalin reuptake, has been reported to improve RLS symptoms in some patients. ${ }^{151,152} \mathrm{~A}$ double-blind, randomised, controlled trial involving 29 patients who had moderate to severe RLS receiving bupropion $150 \mathrm{mg} /$ day and 31 controls receiving placebo showed a significant improvement in IRLSSGRS score for bupropion at 3 weeks $(p=0.016)$, but the difference did not reach statistical significance at 6 weeks. ${ }^{153}$

\section{Antiepileptic Drugs Gabapentin}

Supplementary Table 7 summarises the studies on the efficacy of gabapentin (gabapentin enacarbil in most of them) in the treatment of RLS. ${ }^{154-168}$ Most of them showed a significant and considerable efficacy of different doses of gabapentin in relation with placebo. Two studies showed maintenance of the efficacy over the long term, ${ }^{163,166}$ and others demonstrated similar efficacy for gabapentin as for ropinirole. ${ }^{158}$

VanMeter et al. ${ }^{169}$ analysed the summarised results (efficacy and safety) of three 12-week studies, involving 760 patients, using gabapentin 600 (163 patients), 1,200 (269 patients), 1,800 (38 patients) and 2,400 mg/ day (45 patients) or placebo (245 patients). They found a significant short-term improvement in IRLSSGRS score (13.6 60.71 versus 9.3 \pm 0.55 ; $\mathrm{p}<0.0001)$, and in CGI-I responder rate (70.2\% versus $42.2 \%$; $p<0.0001$ ) for gabapentin $600 \mathrm{mg}$ compared with placebo, with similar benefits for the three higher doses of gabapentin. However, most studies suggest that the most effective dose, for improving both RLS symptoms and associated sleep disturbances, is $1,200 \mathrm{mg} /$ day. ${ }^{170}$

Sun et al., ${ }^{171}$ in a mixed treatment comparison of gabapentin enacarbil, pramipexole, ropinirole and rotigotine (compared with placebo) in moderate to severe RLS, in which they identified 28 clinical trials, showed similar efficacies for the four active drugs assessed by changes in IRLSSGRS scores, IRLS responders, CGI-I responders and RLS-6 scores (with the exception of higher changes in IRLSSGRS for rotigotine than for ropinirole).

\section{Pregabalin}

The efficacy of pregabalin in the treatment of RLS was first reported in a preliminary study involving 16 secondary RLS (most of them resulting from neuropathy) and three iRLS, which showed subjective improvement in RLS symptoms in 16 patients (the other three withdrew the drug because of side effects), with a mean daily dose of $305 \pm 185 \mathrm{mg}$ during a mean of 217 of follow-up. ${ }^{172}$

A double-blind, randomised, placebo-controlled trial with PSG control involving 58 patients (selected from 98 patients who underwent a single-blind phase with placebo) showed a higher IRLS responder rate (63\% versus $38.2 \%$; $p<0.05$ ); a greater improvement in CGI-I, RLS-6 scale and Medical Outcomes Study Sleep Scale ( $p<0.01$ each); a greater reduction in the PLMI $(p<0.001)$ and improvement in sleep architecture with an increase in slow wave sleep $(p<0.01)$ and decrease in wake after sleep onset and stages 1 and $2(p<0.05)$ for pregabalin (mean dose $322.50 \pm 98.77 \mathrm{mg} /$ day) than for placebo. ${ }^{173}$

A 6-week, six-arm (pregabalin 50, 100, 150, 300 or 450 mg or placebo), randomised, double-blind, placebo-controlled dose-response study involving 137 patients who had moderate to severe iRLS showed a significantly higher improvement in the IRLSSGRS score for pregabalin (with mean dose of $123.9 \mathrm{mg}$ providing $90 \%$ efficacy), as well as a higher proportion of CGI-I responders for 300 and $450 \mathrm{mg}$ of pregabalin. ${ }^{174}$

Two further studies compared the efficacy of pregabalin with pramipexole. García-Borreguero et al., ${ }^{175}$ in a 4 -week randomised, double-blind, crossover trial with PSG, involving 85 patients with moderate to severe iRLS who used pregabalin $300 \mathrm{mg}$ /day, pramipexole $0.5 \mathrm{mg} /$ day and placebo, showed a significant improvement in sleep maintenance $(p<0.0001)$ and in the number of awakenings after sleep onset $(p<0.0001)$ and an increase in subjective total sleep time $(p<0.0001)$ and in slow wave duration $(p<0.0001)$ for pregabalin than for pramipexole and placebo, as well as a significant reduction in PLMAI compared with placebo $(p<0.0001)$ that was similar to that obtained with pramipexole.

Allen et al., ${ }^{176}$ in a 52-week randomised, double-blind trial assigned 719 patients to pregabalin $300 \mathrm{mg} /$ day, pramipexole $0.25-0.5 \mathrm{mg} /$ day or 12 weeks of placebo followed by 40 weeks of active treatment with these drugs. Patients treated with pregabalin showed greater reduction IRLSSGRS score $(p<0.001)$ and higher percentage of CGI-I than those treated with placebo $(71.4 \%$ versus $46.8 \%$; $p<0.001)$ at 12 weeks, and the rate of augmentation over $40-52$ weeks was significantly lower with pregabalin than with pramipexole $0.5 \mathrm{mg}(2.1 \%$ versus $7.7 \%$; $p=0.001)$ but not than with pramipexole $1 \mathrm{mg}(5.3 \%$; $\mathrm{p}=0.08)$.

\section{Other Antiepileptic Drugs}

Slow-release valproic acid $600 \mathrm{mg}$ showed similar efficacy to slowrelease 50/200 benserazide/levodopa in reducing PLMS and PLM arousal index, with a higher decrease of intensity and duration of RLS symptoms for valproic acid $(\mathrm{p}=0.022)$, in a randomised, placebocontrolled, crossover double-blind study involving 20 RLS patients. ${ }^{177}$

Data from a preliminary study with six patients showed improvement in several patients with carbamazepine, ${ }^{178}$ and a double-blind study involving 174 patients showed a significant improvement of RLS symptoms both for placebo and carbamazepine ( $p<0.01$ for both), with a significantly higher efficacy for carbamazepine $(p=0.03) .{ }^{179,180}$ 
Several anecdotal reports described improvement or RLS symptoms with topiramate, ${ }^{181}$ lamotrigine, ${ }^{182}$ levetiracetam ${ }^{183,184}$ and oxcarbazepine. ${ }^{185}$

\section{Opiates}

The first observations of improvement of RLS ${ }^{186-189}$ and of PLMS ${ }^{190}$ with opiates including oxycodone ${ }^{186}$ were reported approximately 30 years ago. Moreover, intrathecal or peridural administration of morphine has shown relief of RLS symptoms in several patients with severe RLS. ${ }^{191-196}$ RLS has been described as a transient complication of opiates withdrawal, ${ }^{197}$ although treatment with the opioid antagonist naloxone worsened neither RLS symptoms nor periodic movements during sleep and did not alter adrenocorticotropic hormone, cortisol, PRL or GH levels in drug-naive RLS patients. ${ }^{198}$

The efficacy of tramadol (50-150 mg/day in an evening dose) has been assessed in an open-label study with a follow-up period of 1524 months, involving 12 RLS patients, in which 10 patients reported a significant improvement, other slight amelioration and other no effect, and none reported major tolerance problems. ${ }^{199}$ Several patients under tramadol therapy for RLS showed augmentation. 200,201

The efficacy of oxycodone was assessed in two studies. A 2-week randomised, double-blind, placebo-controlled, crossover trial involving 11 RLS patients showed significant improvement in leg sensations $(p<0.009)$, motor restlessness $(p<0.006)$ and daytime alertness $(p<0.03)$, and reduction in $\mathrm{PLMS} /$ hour sleep $(\mathrm{p}<0.004)$ and in the number of arousals/hour sleep ( $p<0.009$ ), for oxycodone (mean dose $15.9 \mathrm{mg} /$ day) in comparison with baseline or placebo. ${ }^{202}$

A further multicentre, 12-week randomised, double-blind, placebocontrolled trial followed by a 40-week open-label extension phase involved 276 patients who had severe RLS (mean IRLSSGRS score $31.6 \pm 4.5$ points), who were randomised to prolonged release oxycodone/naloxone $(5 / 2.5 \mathrm{mg} / 12$ hours as initial doses, up to a maximum of 40/20 mg/12 hours, 132 patients) or to placebo (144 patients). In the extension phase, the 190 patients enrolled also used oxycodone/naloxone 5/2.5 mg/12 hours as initial doses, up to a maximum of 40/20 mg/12 hours. At 12 weeks, the mean improvement in IRLSSGRS scores was superior for the prolonged release oxycodone/naloxone group $(16.5 \pm 11.3$ versus $9.4 \pm 10.9$ for placebo; $p<0.0001)$. The IRLSSGS score at the final of the extension phase was $9.7 \pm 7.8$. Seventy-three per cent of patients of oxycodone/ naloxone versus $43 \%$ of the placebo group in the double-blind phase and $57 \%$ of patients during the extension phase reported adverse events, but only in $2 \%$ under oxycodone/naloxone were they serious (vomiting with concurrent duodenal ulcer, constipation, subileus, ileus, and acute flank pain). ${ }^{203}$

The efficacy of the synthetic opiate methadone in the treatment of RLS was first reported by Ondo, ${ }^{204}$ who administered methadone 5-40 mg/day (mean $15.6 \pm 7.7 \mathrm{mg} /$ day) to $27 \mathrm{RLS}$ patients resistant to dopaminergic therapy as added-on therapy. Seventeen patients remained on methadone therapy $15.5 \pm 7.7 \mathrm{mg} /$ day during $23 \pm 12$ months (two died because of chronic renal failure, and five withdrew from treatment because of adverse events, two for lack of efficacy, and one for other reasons) and reported a $75 \%$ reduction of their symptoms, with no cases of augmentation. Silver et al., ${ }^{128}$ in a 10-year longitudinal assessment of methadone in the treatment of RLS involving 76 patients treated with this drug, described a $15 \%$ of withdrawal rate during the first year of treatment (sedation in $4 \%$, depression and anxiety in
$3 \%$, altered consciousness in $3 \%$ and lack of efficacy in $3 \%$ ) and absence of augmentation during the follow-up period.

Finally, Walters et al. ${ }^{205}$ analysed the medical records of 493 patients with RLS. One-hundred and thirteen patients had been on opioid therapy. Thirty-six of these patients were under opiate drugs in monotherapy (23 of them resistant to dopaminergic or other treatments, 20 of them continued in opiate monotherapy during nearly 6 years, only one of the 16 withdrawals was related with addiction or tolerance) and 77 patients used opiates in combination with other drugs. Decrease in PLMS index, PLMS arousal index and PLM while awake index, as well as improvement in sleep parameters (increase in stages 3 and 4 and REM sleep, total sleep time, sleep efficiency and decrease in sleep latency) assessed by PSG in seven patients, was maintained at 7 years of monotherapy.

\section{Benzodiazepines}

After the first description of improvement or RLS with clonazepam by Boghen, ${ }^{206}$ two randomised double-blind crossover trials versus placebo involving short series of RLS patients ${ }^{207,208}$ confirmed these findings. One open-label and two double-blind placebo controlled studies showed efficacy of clonazepam 0.5-2 mg in reducing the PLMS index in PSG studies. ${ }^{209-211}$

There have been described improvements of RLS symptoms ${ }^{212}$ and in PLMS with triazolam, ${ }^{21,214}$ as well as of RLS symptoms with alprazolam²15 and zolpidem ${ }^{216}$ based on anecdotal reports or on short series of patients.

\section{Iron}

Studies on the efficacy of oral and intravenous supplements or iron in RLS (most studies involved patients with low-normal serum ferritin levels) are summarised in supplementary Table 8. ${ }^{217-229}$ Although retrospective chart reviews suggested short-term improvement of RLS with oral iron supplements, ${ }^{219,220}$ the results of short-term randomised, double-blind, placebo-controlled studies were te opposite, 213,218 and other short-term studies showed similar efficacy than pramipexole. ${ }^{219}$

Regarding the efficacy or intravenous iron, the results of the studies summarised in Supplementary Table 8, despite their different designs, suggest short-term improvement of RLS symptoms that are not maintained at long-term follow-up periods.

\section{Botulinum Toxin A}

Rotenberg et al. ${ }^{230}$ reported, in an observational study involving three patients, improvement of refractory RLS with botulinum toxin A (BTXA). All patients were injected in the areas of maximal discomfort in both legs, and one of them in lumbar paraspinal muscles as well. Improvement of RLS symptoms was maintained during 10-12 weeks. In contrast, Ghoyareb and Burbaud ${ }^{231}$ reported lack of improvement of RLS symptoms in another observational study involving three patients (with evaluations at 2, 4 and 6 weeks), and data from a 4-week single-arm, open-label pilot trial involving a short series of patients showed improvement in the IRLSSGRS score, a visual analogue scale measuring pain and PGI-I. ${ }^{232}$

A double-blind, placebo-controlled pilot trial involving seven patients (BTXA was injected in quadriceps femoris [40 units], tibialis anterior [20 units], gastrocnemius [20 units] and soleus [10 units]) showed lack of improvement in IRLSSGRS and in CGI-I scores at the fourth week. ${ }^{233}$ Finally, an optimal two-stage, phase II exploratory, open-label, noncomparative trial involving 27 patients who had moderate to severe 
RLS and who received a series of 20 intradermal injections of $0.05 \mathrm{ml}$ of BTXA showed improvement in the IRLSSGRS score only in six patients, maintained during 46 days. ${ }^{234}$

\section{Other Pharmacological Therapies}

A 1-week double-blind, placebo-controlled, crossover study involving 10 RLS patients showed improvement of low-dose hydrocortisone (40 mg) compared with placebo ( $\mathrm{p}=0.032)$ in the severity of sensory leg discomfort during a suggested immobilisation test (SIT). ${ }^{235}$

A double-blind placebo-controlled crossover trial with hydroquinone (200 mg in the evening and $200 \mathrm{mg}$ before going to bed) involving 68 patients (completed by 59 patients) found lack of improvement using a daily questionnaire and a SIT.236

An 8-week prospective, triple-blinded, randomised, placebo-controlled, parallel design study involving 37 RLS patients showed significant improvement of sleepiness $(p=0.01)$ and IRLSSGRS $(p=0.02)$ with the herbal valerian $\left(800 \mathrm{mg}\right.$ ) compared with placebo. ${ }^{237}$

Several anecdotal reports or open-label studies with short series of patients described improvement of RLS symptoms by the following drug groups:

(a) Drugs acting on cholinergic system: cigarette smoking (attributed to stimulation of nicotine acetylcholine receptors), ${ }^{238}$ varenicline (partial agonist at the alpha4-beta2 nicotinic acetylcholine receptor), ${ }^{239}$ physostigmine (a reversible cholinesterase inhibitor, ${ }^{240,241}$ orphenadrine (an anticholinergic drug of the ethanolamine antihistamine class) ${ }^{242}$ and hydroxyzine ( $\mathrm{H} 1$ antihistaminic with anticholinergic properties). ${ }^{243}$

(b) Drugs acting on adrenergic system, such as the $\alpha_{2}$-adrenergic agonist clonidine, ${ }^{244}$ though other authors reported no improvement with this drug. ${ }^{245}$

(c) Antidepressants, such as amitriptyline, ${ }^{246}$ and selective serotonin receptor uptake inhibitors (SSRI). ${ }^{246}$ Although RLS it is a wellknown adverse effect of SSRI, a retrospective study involving 43 depressed patients having pre-existent RLS symptoms found reduction in $58 \%$, and abolishment of RLS symptoms in $12 \%$, of cases, with only $12 \%$ reporting worsening. ${ }^{24}$

(d) Inhibitors of N-methyl-D-aspartate (NMDA) receptors, e.g. ketamine. ${ }^{248}$

(e) Hormones such as alpha-melanocyte-stimulating hormone (MSH). ${ }^{249}$

(f) Vitamin $E_{1}{ }^{250}$ niacin, ${ }^{251}$ vitamin $D_{1}{ }^{252}$ magnesium ${ }^{253,254}$ or selenium supplements. ${ }^{255}$

(g) Nitroglycerin administered sublingually ${ }^{256}$ or in patches. ${ }^{257}$

(h) Herbs, ${ }^{25,259}$ including yokukansann ${ }^{260}$ and Saint John's wort. ${ }^{261}$

The adenosine $\mathrm{A}_{2} \mathrm{~A}$ receptor istradefylline did not show beneficial effect, ${ }^{262}$ and melatonin caused worsening ${ }^{263}$ of RLS symptoms in short open-label studies.

\section{Non-pharmacological Therapies Acupuncture}

Cui et al. ${ }^{264}$ reported a systematic review on the role of acupuncture in the therapy of RLS up to 2007. Most of the controlled trials were obtained from Asiatic Databases, and only two out of 14 trials with 170 patients met the inclusion criteria. One trial showed no significant differences between acupuncture and medications, and the other showed significant improvement with the combination of acupuncture, massage and mediations in comparison with massage and medications alone, but there were no differences in the duration of RLS symptoms. The efficacy of acupuncture was not sufficiently evident.

Wu et al., ${ }^{265}$ in an observational study involving 158 RLS patients (79 assigned to acupuncture combined with TDP radiation and 79 to levodopa), described higher efficacy of acupuncture combined with TDP radiation (91.1\% versus $30.4 \%$ of improvement rate). Finally, Cripps et al., ${ }^{266}$ in a retrospective observational study, showed a significantly higher improvement in RLS severity in 16 patients without previous dopaminergic treatment than in three treated previously using these drugs.

\section{Exercise}

A 12-week randomised, controlled trial involving 41 iRLS patients (28 of them available, 23 completing the trial, 11 of them have been randomly assigned to exercise and 12 serving as controls) showed significant improvement in the IRLSSGRS scores $(p=0.001)$ and in a ordinal scale $(p<0.001)$ for the group randomly assigned to the exercise programme (aerobic and lower-body resistance training 3 days per week). ${ }^{267}$

\section{Yoga}

An 8-week observational study with a lyengar yoga program, involving 13 iRLS patients (completed by 10 of them) showed significant improvement in the IRLSSGRS in an RLS ordinal score, which was correlated with increasing minutes of homework practice per session and with total homework minutes, as well as significant improvement in sleep, perceived stress and mood scales. ${ }^{268}$

\section{Traction Straight Leg Raise Techniques}

The effects of this technique have been assessed in a 15-day observational study involving a cohort of 15 patients who had iRLS (13 completed the study). There were significant improvements, compared to baseline, in IRLSSGRS score (63\% of reduction; $p<0.05$ ), in an RLS ordinal scale, and in a global rating of change. ${ }^{269}$

\section{Repetitive Transcranial Magnetic and Transcranial Direct Current Stimulation}

A recent prospective, double-blind, randomised study involving 19 iRLS patients (11 randomised to rTMS and eight with sham stimulation) showed a significant reduction in IRLSSGRS scores for the group treated with rTMS after the fifth to the 10th sessions. Moreover, five patients of the sham stimulation who afterwards received real rTMS showed a significant improvement as well. ${ }^{270}$

A 2-week double-blind, randomised, sham-controlled performed in 33 drug-naive females who had RLS using cathodal, anodal and sham tCDS with electrodes on the sensorimotor cortex, making assessments at baseline, 3 days and 13 days, showed lack of improvement in IRLSSGRS scores, CGI-I, PGI scale, Pittsburgh Sleep Quality Index, Medical Outcome Study sleep subscale and Beck depression inventory. ${ }^{271}$

\section{Conclusions}

Dopamine agonists should be considered the first-line drugs for the treatment of iRLS, because most of them have shown a significant improvement compared with placebo (although the degree of improvement with placebo in many of the clinical trials is relatively high). ${ }^{147,148}$ However, several considerations should be noted:

(a) Most of the studies with dopamine agonists have evaluated the results after short-term follow-up periods. Although studies with 
Figure 1: Algorithm Proposed for the Management of Idiopathic Restless Legs Syndrome

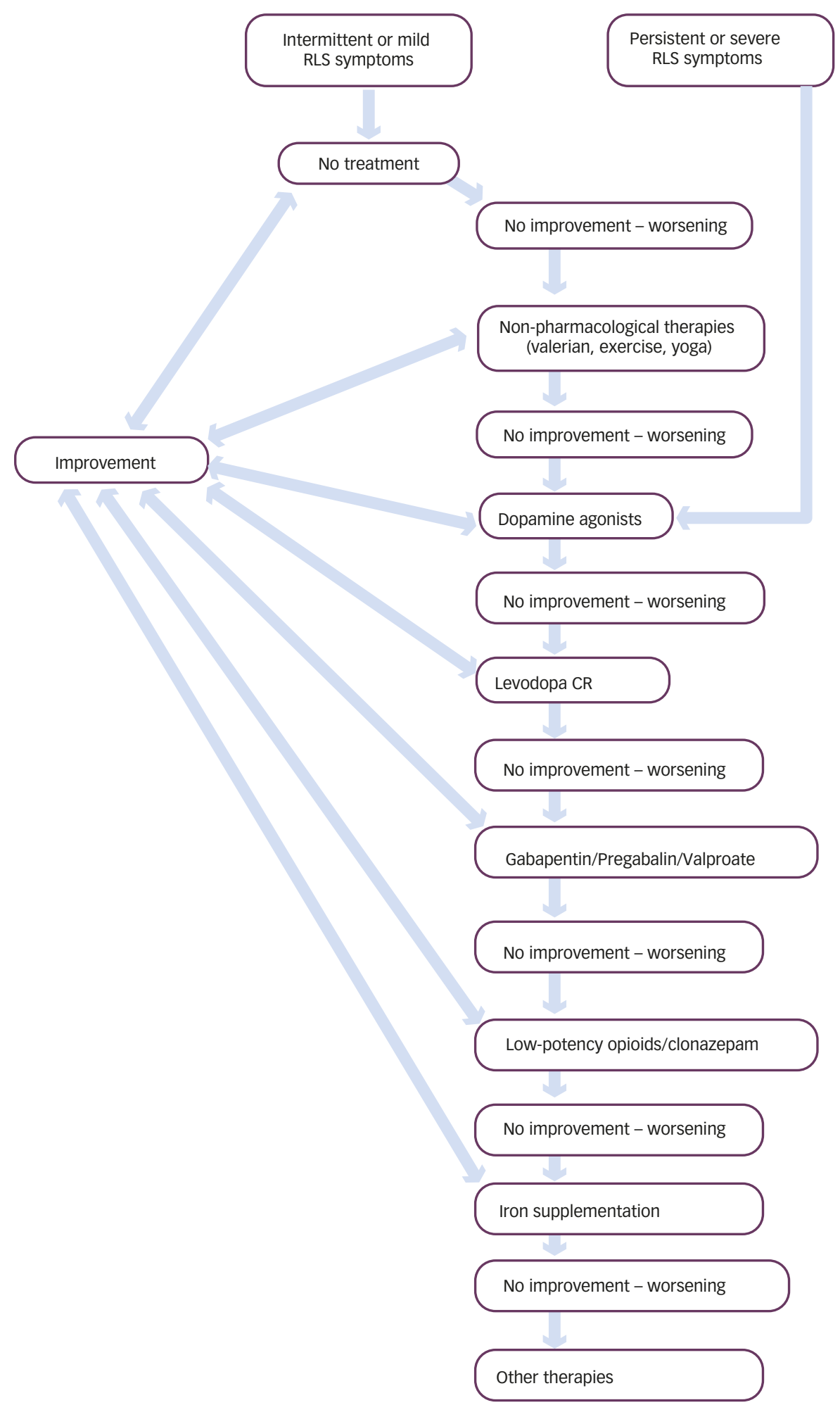

Levodopa $C R=$ controlled-release carbidopa/levodopa; $R L S$ = restless legs syndrome.

follow-up periods longer than 5 years described a high withdrawal rate, the effect of dopamine agonists is maintained across the time in an important percentage of patients. ${ }^{80,127,128}$

(b) Many of the clinical trials have been performed with short-acting dopamine agonists (with the exception of those performed with cabergoline and rotigotine). Although in the clinical setting it is possible that the sustained-release forms of ropinirole and pramipexole might be more useful than the standard-release ones
(Jiménez-Jiménez et al., unpublished data), there are (surprisingly) no reports concerning this matter.

(c) Ergotic derivatives (mainly cabergoline and pergolide), though effective, are not recommended because of the risk of developing cardiac valve fibrosis.

Levodopa should be considered as a good option for those patients who developed adverse effects with dopamine agonists. Although 
its efficacy is similar to that of pramipexole, ${ }^{60}$ and lower than that of pergolide ${ }^{86}$ and cabergoline ${ }^{101}$ (which are not generally recommended because of the risk of cardiac valve fibrosis), the risk for development of rebound or augmentation phenomena is higher than that with dopamine agonists. It is possible that the frequency of these complications could be lessened with the use of sustained-release preparations, ${ }^{19}$ but to our knowledge, there are no comparative studies between sustained and standard release preparations of levodopa.

Gabapentin should be considered, as with dopamine agonists, as a first-line therapy for iRLS, with a similar degree of efficacy to ropinirole, pramipexole and rotigotine. ${ }^{171}$ The same observation could be made of pregabalin, which was slightly superior to pramipexole in improving several sleep parameters in short-term studies ${ }^{175}$ and showed similar efficacy to pramipexole (but with less risk of augmentation) in long-term studies. ${ }^{176}$ Although studies with valproic acid ${ }^{177}$ and carbamazepine ${ }^{179,180}$ are scarce, these might be useful as alternative treatments when first-line drugs have not been useful.

Opiate drugs, mainly oxycodone or methadone, alone or in combination, have shown efficacy in the control of RLS symptoms, ${ }^{202-205}$ maintained across time in many patients, ${ }^{128,204,205}$ with no cases of augmentation. ${ }^{128,204}$ Although patients under opiate treatment risk developing addiction and tolerance, the withdrawal rate reported for these complications was approximately $6 \%{ }^{205}$ These drugs should be considered as an alternative therapy for patients who have RLS who have been unresponsive to dopamine agonists or antiepileptic drugs.
Benzodiazepines, in particular clonazepam, have shown efficacy in short series of patients both in the improvement of RLS symptoms and, especially, in reducing PLMS. This drug should be considered as a useful add-on therapy in patients who have high PLMI.

Though the results surrounding the oral supplementation of iron to control RLS symptoms are controversial, the efficacy of intravenous iron is well established, and it should be considered as a useful add-on therapy for refractory RLS. Unfortunately, the duration of the pharmacological effect is short.

The possible role of valerian (a herb having a good profile of side effects), which has shown short-term improvement of RLS symptoms in a triple-blinded, placebo-controlled study with a low sample size, ${ }^{237}$ seems to be promising, though it awaits confirmation with long-term studies involving greater numbers of patients. Other drugs have not proved their efficacy in the treatment of RLS.

Among non-pharmacological therapies, preliminary studies on exercise, ${ }^{267}$ yoga $^{268}$ traction straight leg raise techniques ${ }^{269}$ and repetitive transcranial stimulation ${ }^{270}$ have shown possible efficacy, though transcranial direct current stimulation was not useful271 and the role of acupuncture remains to be determined.

The main conclusions of this review are in the same line as those of several guidelines published in recent years. ${ }^{272-278} \mathrm{~A}$ proposed algorithm for the management of iRLS is depicted in Figure 1 .
1. Allen RP, Picchietti D, Hening WA, et al., Restless legs syndrome: diagnostic criteria, special considerations, and epidemiology - a report from the Restless Legs Syndrome Diagnosis and epidemiology Workshop at the National Institute of Health, Sleep Med, 2003;4:101-19.

2. Allen RP, Picchietti DL, Garcia-Borreguero D, et al., International Restless Legs Syndrome Study Group, Restless legs syndrome/Willis-Ekbom disease diagnostic criteria: updated International Restless Legs Syndrome Study Group (IRLSSG) consensus criteria - history, rationale, description, and significance, Sleep Med, 2014;15:860-73.

3. Jiménez-Jiménez FJ, Alonso-Navarro H, García-Martín E, Agúndez JAG, Latest perspectives in genetic risk factors for Agundez JAG, Latest perspectives in genetic risk fact
restless legs syndrome, Eur Neurol Rev, 2013;8:90-6.

4. Jiménez-Jiménez FJ, Alonso-Navarro H, García-Martín E, Agúndez JAG, Neurochemistry of idiopathic restless legs Agundez JAG, Neurochemistry of idiopathic
syndrome, Eur Neurol Rev, 2015;10:35-44.

5. Akpinar $S$, Treatment of restless legs syndrome with levodopa plus benserazide, Arch Neurol, 1982;39:739.

6. Montplaisir J, Godbout R, Poirier G, Bédard MA, Restless legs syndrome and periodic movements in sleep: physiopathology and treatment with L-dopa, Clin Neuropharmacol, 1986;9:456-63.

7. von Scheele C. Levodopa in restless legs, Lancet, 1986;2 426-7.

8. Akpinar $S$, Restless legs syndrome treatment with dopaminergic drugs, Clin Neuropharmacol, 1987;10:69-79.

9. Brodeur C, Montplaisir J, Godbout R, Marinier R, Treatment of restless legs syndrome and periodic movements during sleep with L-dopa: a double-blind, controlled study, Neurology, 1988:38:1845-8.

10. von Scheele $C$, Kempi V, Long-term effect of dopaminergic drugs in restless legs: a 2-year follow-up, Arch Neurol, drugs in restless
1990;47:1223-4.

11. Becker PM, Jamieson AO, Brown WD, Dopaminergic agents in restless legs syndrome and periodic limb movements of sleep: response and complications of extended treatment in 49 cases, Sleep, 1993;16:713-6

12. Trenkwalder $C$, Stiasny $K$, Pollmächer T, et al., L-dopa therapy of uremic and idiopathic restless legs syndrome: a doubleblind, crossover trial, Sleep, 1995;18:681-8.

13. Wetter TC, Trenkwalder C, Stiasny K, et al., Treatment of idiopathic and uremic restless legs syndrome with L-dopa - a double-blind cross-over study, Wien Med Wochenschr, 1995;145:525-7.

14. Collado-Seidel V, Kazenwadel J, Wetter TC, et al., A controlled study of additional Sr-L-dopa in L-dopa-responsive restless legs syndrome with late-night symptoms, Neurology, 1999;52:285-90.

15. Benes H, Kurella B, Kummer J, et al., Rapid onset of action of levodopa in restless legs syndrome: a double-blind, randomized, multicenter, crossover trial, Sleep, 1999;22 1073-81.
16. Trenkwalder C, Collado Seidel V, Kazenwadel J, et al., One-year treatment with standard and sustained-release levodopa: appropriate long-term treatment of restless legs syndrome? Mov Disord, 2003;18:1184-9.

17. Saletu M, Anderer P, Högl B, et al., Acute double-blind, placebo-controlled sleep laboratory and clinical follow-up studies with a combination treatment of rr-L-dopa and Sr-L-dopa in restless legs syndrome, I Neural Transm, 2003;110:611-26

18. Stiasny-Kolster K, Kohnen R, Möller JC, et al., Validation of the "L-DOPA test" for diagnosis of restless legs syndrome, Mov Disord, 2006;21:1333-9.

19. Guilleminault $C$, Cetel M, Philip P, Dopaminergic treatment of restless legs and rebound phenomenon, Neurology, 1993:43:445.

20. García-Borreguero D, Williams AM, Dopaminergic augmentation of restless legs syndrome, Sleep Med Rev, 2010;14:339-46.

21. Allen RP, Earley CJ, Augmentation of the restless legs syndrome with carbidopa/levodopa, Sleep, 1996;19:205-13

22. Vetrugno $R$, Contin M, Baruzzi A, et al., Polysomnographic and pharmacokinetic findings in levodopa-induced augmentation of restless legs syndrome, Mov Disord, 2006;21:254-8.

23. Garcia-Borreguero D, Larrosa O, Granizo JJ, et al., Circadian variation in neuroendocrine response to $\mathrm{L}$-dopa in patients with restless legs syndrome, Sleep, 2004;27:669-73.

24. Garcia-Borreguero D, Serrano C, Larrosa O, Granizo IJ, Circadian effects of dopaminergic treatment in restless legs syndrome, Sleep Med, 2004;5:413-20.

25. Conti CF, de Oliveira MM, Andriolo RB, et al., Levodopa for idiopathic restless legs syndrome: evidence-based review, Mov Disord, 2007:22:1943-51.

26. Scholz $\mathrm{H}$, Trenkwalder $\mathrm{C}$, Kohnen $\mathrm{R}$, et al., Levodopa for restless legs syndrome, Cochrane Database Syst Rev, 2011;(2):CD005504.

27. Sharif AA, Entacapone in restless legs syndrome, Mov Disord 2002;17:421

28. Polo O, Ylä-Sahra R, Hirvonen K, et al., Entacapone prolongs the reduction of PLM by levodopa/carbidopa in restless legs syndrome, Clin Neuropharmacol, 2007;30:335-44.

29. Ondo W, Ropinirole for restless legs syndrome, Mov Disord, 1999;14:138-40.

30. Estivill $E$, de la Fuente $V$, The use of ropinirole ++ as a treatment for restless leg syndrome, Rev Neurol, 1999;28:962-3

31. Estivill $E$, de la Fuente $V$, The efficacy of ropinirole in the treatment of chronic insomnia secondary to restless legs syndrome: polysomnography data, Rev Neurol, 1999;29: 805-7.

32. Adler $\mathrm{CH}$, Hauser RA, Sethi $\mathrm{K}$, et al., Ropinirole for restless legs syndrome: a placebo-controlled crossover trial, Neurology, 2004:62:1405-7.

33. Walters AS, Ondo WG, Dreykluft T, et al., TREAT RLS 2 (Therapy with Ropinirole: Efficacy And Tolerability in RLS 2) Study Group, Ropinirole is effective in the treatment of restles legs syndrome - TREAT RLS 2: a 12-week, double-blind, randomized, parallel-group, placebo-controlled study, Mov Disord, 2004;19:1414-23.

34. Allen R, Becker PM, Bogan R, et al., Ropinirole decreases periodic leg movements and improves sleep parameters in patients with restless legs syndrome, Sleep, 2004;27:907-14

35. Trenkwalder C, Garcia-Borreguero D, Montagna P, et al. Therapy with Ropinirole, Efficacy and Tolerability in RLS 1 Study Group, Ropinirole in the treatment of restless legs syndrome: results from the TREAT RLS 1 study, a 12 week, randomised, placebo controlled study in 10 European randomised, placebo controlled study in 10 European
countries, I Neurol Neurosurg Psychiatry, 2004;75:92-7.

36. Bliwise DL, Freeman A, Ingram CD, et al., Randomized, double-blind, placebo-controlled, short-term trial of ropinirole double-blind, placebo-controlled, short-term trial of
in restless legs syndrome, Sleep Med, 2005;6:141-7.

37. Montplaisir J, Karrasch J, Haan J, Volc D, Ropinirole is effective in the long-term management of restless legs syndrome: a randomized controlled trial, Mov Disord, 2006;21:1627-35.

38. Bogan RK, Fry JM, Schmidt MH, et al., TREAT RLS US Study Group, Ropinirole in the treatment of patients with restless legs syndrome: a US-based randomized, double-blind, placebocontrolled clinical trial, Mayo Clin Proc, 2006;81:17-27.

39. Garcia-Borreguero D, Grunstein R, Sridhar G, et al., A 52week open-label study of the long-term safety of ropinirole in patients with restless legs syndrome, Sleep Med, 2007;8:742-52.

40. Cho YW, Hong SB, Kim do H, et al., The effect of ropinirole on the quality of life in patients with restless legs syndrome in Korea: an 8-week, multicenter, prospective study, I Clin in Korea: an 8-week,

41. Giorgi $L, A s g h a r i a n A$, Hunter $B$, Ropinirole in patients with restless legs syndrome and baseline IRLS total scores $\geq 24$ : efficacy and tolerability in a 26 -week, double-blind, parallelgroup, placebo-controlled study followed by a 40-wee open-label extension, Clin Ther, 2013;35:1321-36.

42. Becker PM, Ondo W, Sharon D, Encouraging initial response of restless legs syndrome to pramipexole, Neurology, 1998;51:1221-3.

43. Lin SC, Kaplan J, Burger CD, Fredrickson PA, Effect of pramipexole in treatment of resistant restless legs syndrome, Mayo Clin Proc, 1998;73:497-500.

44. Montplaisir J, Nicolas A, Denesle R, Gomez-Mancilla B, Restless legs syndrome improved by pramipexole: a doubleblind randomized trial, Neurology, 1999;52:938-43.

45. Montplaisir J, Denesle R, Petit D, Pramipexole in the treatment of restless legs syndrome: a follow-up study, Eur J Neurol, 2000:7(Suppl. 1):27-31

46. Stiasny K, Möller JC, Oertel WH, Safety of pramipexole in patients with restless legs syndrome, Neurology, 2000;55:1589-90.

47. Silber MH, Girish M, Izurieta R, Pramipexole in the 
management of restless legs syndrome: an extended study,

48. Manconi M, Casetta I, Govoni V, et al., Pramipexole in Restless Legs syndrome: evaluation by suggested immobilization test, J Neurol, 2003;250:1494-5.

49. Stiasny-Kolster K, Oertel WH, Low-dose pramipexole in the management of restless legs syndrome: an open label trial, Neuropsychobiology, 2004:50:65-70.

50. Merlino $G$, Dolso $P$, Canesin $R$, et al., The acute effect of a low dosage of pramipexole on severe idiopathic restless legs syndrome: an open-label trial, Neuropsychobiology, 2006;54:195-200.

51. Partinen $M$, Hirvonen $K$, Jama $L$, et al., Efficacy and safety of pramipexole in idiopathic restless legs syndrome: a polysomnographic dose-finding study - the PRELUDE study, Sleep Med, 2006;7:407-17.

52. Winkelman JW, Sethi KD, Kushida CA, et al., Efficacy and safety of pramipexole in restless legs syndrome, Neurology, 2006;67:1034-9

53. Montplaisir J, Fantini ML, Desautels A, et al., Long-term treatment with pramipexole in restless legs syndrome, Eur J Neurol, 2006:13:1306-11.

54. Manconi M, Ferri R, Zucconi M, et al., First night efficacy of pramipexole in restless legs syndrome and periodic leg movements, sleep Med, 2007:8:491-7.

55. Oertel WH, Stiasny-Kolster K, et al., Pramipexole RLS Study Group, Efficacy of pramipexole in restless legs syndrome: a six-week, multicenter, randomized, double-blind study (effectRLS study), Mov Disord, 2007;22:213-9.

56. Ferini-Strambi L, Aarskog D, Partinen M, et al., Effect of pramipexole on RLS symptoms and sleep: a randomized, double-blind, placebo-controlled trial, Sleep Med, 2008;9: $874-81$

57. Partinen M, Hirvonen K, Jama L, et al., Open-label study of the long-term efficacy and safety of pramipexole in patients with restless legs syndrome (extension of the PRELUDE study), Sleep Med, 2008;9:537-41.

58. Jama L, Hirvonen K, Partinen M, et al., A dose-ranging study of pramipexole for the symptomatic treatment of restless legs syndrome: polysomnographic evaluation of periodic leg movements and sleep disturbance, Sleep Med, 2009;10: 630-6.

59. Ferri R, Manconi M, Aricò D, et al., Acute dopamine-agonist treatment in restless legs syndrome: effects on sleep architecture and NREM sleep instability, Sleep, 2010;33: 793-800

60. Kallweit U, Khatami R, Pizza F, et al., Dopaminergic treatment in idiopathic restless legs syndrome: effects on subjective sleepiness, Clin Neuropharmacol, 2010;33:276-8.

61. Inoue Y, Hirata K, Kuroda K, et al., Efficacy and safety of pramipexole in Japanese patients with primary restless legs syndrome: a polysomnographic randomized, double-blind, placebo-controlled study, Sleep Med, 2010;11:11-6.

62. Inoue Y, Kuroda K, Hirata K, et al., Long-term open-label study of pramipexole in patients with primary restless legs syndrome, I Neurol Sci, 2010;294:62-6.

63. Shinno H, Oka Y, Otsuki M, et al., Proposed dose equivalence between clonazepam and pramipexole in patients with restless legs syndrome, Prog Neuropsychopharmacol Biol Psychiatry, 2010;34:522-6.

64. Inoue $Y$ Kuroda $K$ Hirata $K$, et al., Efficacy, safety and dose-response of pramipexole in Japanese patients with primary restless legs syndrome: randomized trial, Neuropsychobiology, 2011;63:35-42.

65. Montagna P, Hornyak M, Ulfberg J, et al., Randomized trial of pramipexole for patients with restless legs syndrome (RLS) and RLS-related impairment of mood, Sleep Med, 2011;12:34-40

66. Högl B, Garcia-Borreguero D, Trenkwalder C, et al., Efficacy and augmentation during 6 months of double-blind pramipexole for restless legs syndrome, Sleep Med, 2011;12:351-60.

67. Manconi M, Ferri R, Zucconi M, et al., Pramipexole versus ropinirole: polysomnographic acute effects in restless legs syndrome, Mov Disord, 2011:26:892-5.

68. Manconi M, Ferri R, Zucconi M, et al., Preferential D2 or preferential D3 dopamine agonists in restless legs syndrome Neurology, 2011:77:110-7.

69. Bassetti CL, Bornatico F, Fuhr P, et al., Swiss RLS study group, Pramipexole versus dual release levodopa in restless legs syndrome: a double blind, randomised, cross-over trial Swiss Med Wkly, 2011;141:w13274.

70. Ma JF, Wan Q, Hu XY, et al., Efficacy and safety of pramipexole in Chinese patients with restless legs syndrome: results from a multi-center, randomized, double-blind, placebo-controlled trial, Sleep Med, 2012;13:58-63.

71. Lipford MC, Silber MH, Long-term use of pramipexole in the management of restless legs syndrome, Sleep Med, 2012;13:1280-5.

72. Rezvani M, Zamani B, Fereshtehnejad SM, Factors affecting the efficacy of pramipexole in patients with restless legs syndrome, Acta Med Iran, 2013;51:377-85.

73. Zhang J, Liu B, Zheng Y, et al., Pramipexole for Chinese people with primary restless legs syndrome: a 12-week multicenter with primary restless legs syndrome: a 12-week multicenter,

74. Stiasny-Kolster K, Kohnen R, Schollmayer E, et al., Rotigotine Sp 666 Study Group, Patch application of the dopamine agonist rotigotine to patients with moderate to advanced stages of restless legs syndrome: a double-blind, placebocontrolled pilot study, Mov Disord, 2004;19:1432-8.

75. Oertel WH, Benes H, Garcia-Borreguero D, et al., Rotigotine SP 709 Study Group, Efficacy of rotigotine transdermal system in severe restless legs syndrome: a randomized, double-blind, placebo-controlled, six-week dose-finding trial in Europe Sleep Med, 2008:9:228-39.

76. Trenkwalder C, Benes H, Poewe W, et al., SP790 Study Group, Efficacy of rotigotine for treatment of moderate-to-severe restless legs syndrome: a randomised, double-blind, placebocontrolled trial, Lancet Neurol, 2008:7:595-604.

77. Oertel WH, Benes H, Garcia-Borreguero D, et al., Rotigotine SP710 Study Group, One year open-label safety and efficacy trial with rotigotine transdermal patch in moderate to sever idiopathic restless legs syndrome, Sleep Med, 2008;9:865-73.

78. Hening WA, Allen RP, Ondo WG, et al., SP792 Study Group, Rotigotine improves restless legs syndrome: a 6-month randomized, double-blind, placebo-controlled trial in the United States, Mov Disord, 2010;25:1675-83.

79. Oertel WH, Benes H, Garcia-Borreguero D, et al., Rotigotine transdermal patch in moderate to severe idiopathic restless legs syndrome: a randomized, placebo-controlled polysomnographic study, Sleep Med, 2010;11:848-56.

80. Oertel W, Trenkwalder C, Beneš H, et al., SP710 study group, Long-term safety and efficacy of rotigotine transdermal patch for moderate-to-severe idiopathic restless legs syndrome: a 5-year open-label extension study, Lancet Neurol, 2011;10:710-20.

81. Högl B, Oertel WH, Schollmayer E, Bauer L, Transdermal rotigotine for the perioperative management of restless legs syndrome, BMC Nourol, 2012:12:106.

82. Dohin E, Högl B, Ferini-Strambi L, et al., Safety and efficacy of rotigotine transdermal patch in patients with restless legs syndrome: a post-hoc analysis of patients taking 1-3 mg/24 for up to 5 years, Expert Opin Pharmacother, 2013;14:15-25.

83. Inoue Y, Hirata K, Hayashida K, et al., Rotigotine Study Group, Efficacy, safety and risk of augmentation of rotigotine for treating restless legs syndrome, Prog Neuropsychopharmaco Biol Psychiatry, 2013;40:326-33.

84. Stiasny-Kolster K, Berg D, Hofmann WE, et al., Effectiveness and tolerability of rotigotine transdermal patch for the treatment of restless legs syndrome in a routine clinica practice setting in Germany, Sleep Med, 2013:14:475-81.

5. Inou Y Shimizu T, Hirata K, to Efficacy and safety of rotigotine in Japanese patients with restless legs syndrome: a phase 3 , multicenter, randomized placebo-controlled, double-blind, parallel-group study, Sleep Med, 2013:14:1085-91.

86. Staedt J, Wassmuth F, Ziemann U, et al., Pergolide: treatment of choice in restless legs syndrome (RLS) and nocturnal myoclonus syndrome (NMS) - a double-blind randomized crossover trial of pergolide versus L-Dopa, J Neural Transm 1997;104:461-8

87. Silber MH, Shepard JW Jr, Wisbey JA, Pergolide in the management of restless legs syndrome: an extended study, Sleep, 1997;20:878-82

88. Noël S, Korri H, Vanderheyden JE, Low dosage of pergolide in the treatment of restless legs syndrome, Acta Neurol Belg. 1998:98:52-3

89. Staedt J, Hünerjäger $H$, Rüther E, Stoppe G, Pergolide: treatment of choice in restless legs syndrome (RLS) and nocturnal myoclonus syndrome (NMS)-long-term follownocturnal myoclonus syndrome (NMS)-long-term follow1998;105:265-8.

90. Earley CJ, Yaffee JB, Allen RP, Randomized, double-blind, placebo-controlled trial of pergolide in restless legs syndrome, Neurology, 1998;51:1599-602.

91. Winkelmann J, Wetter TC, Stiasny K, et al., Treatment of restless leg syndrome with pergolide-an open clinical trial, Mov Disord, 1998;13:566-9.

92. Wetter TC, Stiasny K, Winkelmann J, et al., A randomized controlled study of pergolide in patients with restless leg syndrome, Neurology, 1999;52:944-50

93. Stiasny K, Wetter TC, Winkelmann J, et al., Long-term effects of pergolide in the treatment of restless legs syndrome, Neurology, 2001:56:1399-402.

94. Trenkwalder C, Hundemer HP, Lledo A, et al., PEARLS Study Group, Efficacy of pergolide in treatment of restless legs syndrome: the PEARLS Study, Neurology, 2004;62:1391-7.

95. Stiasny K Röbbecke J, Schüler P. Oertel WH Treatment of idiopathic restless legs syndrome (RLS) with the D2-agonist cabergoline en lop linical trial Sleep, 2000:23.349-54.

96. Zucconi M Oldani A Castronovo C, Ferini-Strambi L. Cabergoline is an effective single-drug treatment for restles legs syndrome: clinical and actigraphic evaluation, Sleep 2003;26:815-8

97. Benes $\mathrm{H}$, Heinrich CR, Ueberall MA, Kohnen R, Long-term safety and efficacy of cabergoline for the treatment of idiopathic restless legs syndrome: results from an open-labe 6-month clinical trial, Sleep, 2004;27:674-82.

98. Stiasny-Kolster K, Benes H, Peglau I, et al., Effective cabergoline treatment in idiopathic restless legs syndrome, Neurology, 2004;63:2272-9.

99. Aizawa H, Aburakawa Y, Suzuki Y, et al., Treatment of Japanese restless legs syndrome patients with cabergoline: an open clinical preliminary trial, Intern Med, 2006;45:453-5.

00. Oertel WH, Benes $H$, Bodenschatz R, et al., Efficacy of cabergoline in restless legs syndrome: a placebo-controlled study with polysomnography (CATOR), Neurology 2006;67:1040-6.

101. Trenkwalder $C$, Benes $H$, Grote L, et al., CALDIR Study Group Cabergoline compared to levodopa in the treatment of patients with severe restless legs syndrome: results from a multi-center, randomized, active controlled trial, Mov Disord 2007;22:696-703.

102. Garcia-Borreguero D, Winkelman J, Adams A, et al.,

Sumanirole in RLS Study Group, Efficacy and tolerability of sumanirole in restless legs syndrome: a phase II, randomized, double-blind, placebo-controlled, dose-response study, Sleep Med, 2007;8:119-27.

103. Walters AS, Hening WA, Kavey N, et al., A double-blind randomized crossover trial of bromocriptine and placebo in restless legs syndrome, Ann Neurol, 1988;24:455-8.

104. Inoue $Y$, Mitani $H$, Nanba K, Kawahara R, Treatment of periodic leg movement disorder and restless leg syndrome with talipexole, Psychiatry Clin Neurosci, 1999;53:283-5.

105. Evidente VG, Adler $\mathrm{CH}$, Caviness JN, et al., Amantadine
is beneficial in restless legs syndrome, Mov Disord, 2000;15:324-7.

106. Tergau F, Wischer S, Wolf C, Paulus W, Treatment of restless legs syndrome with the dopamine agonist alphadihydroergocryptine, Mov Disord, 2001;16:731-5.

107. Evidente VG, Piribedil for restless legs syndrome: a pilot study, Mov Disord, 2001;16:579-81.

108. Sonka K, Pretl M, Kranda K, Management of restless legs syndrome by the partial D2-agonist terguride, sleep Med, 2003;4:455-7.

109. MCLean AJ, The use of the dopamine-receptor partial agonist aripiprazole in the treatment of restless legs syndrome, Sleep 2004:27:1022.

110. Reuter I, Ellis CM, Ray Chaudhuri K, Nocturnal subcutaneous apomorphine infusion in Parkinson's disease and restless legs syndrome, Acta Neurol Scand, 1999;100:163-7.

111. Tings T, Stiens G, Paulus W, et al., Treatment of restless legs syndrome with subcutaneous apomorphine in a patient with short bowel syndrome, I Neurol, 2005;252:361-3.

12. Tribl GG, Sycha T, Kotzailias N, et al., Apomorphine in idiopathic restless legs syndrome: an exploratory study, I Neurol Neurosurg Psychiatry, 2005;76:181-5.

113. Benes $H$, Transdermal lisuride: short-term efficacy and tolerability study in patients with severe restless legs syndrome, sleep Med, 2006;7:31-5.

114. Benes H, Deissler A, Rodenbeck A, et al., Lisuride treatment of restless legs syndrome: first studies with monotherapy in de novo patients and in combination with levodopa advanced disease, I Neural Transm, 2006;113:87-92.

115. Hansen RA, Song L, Moore CG, et al.. Effect of ropinirole on sleep outcomes in patients with restless legs syndrome: meta-analysis of pooled individual patient data from randomized controlled trials, Pharmacotherapy, 2009;29: $255-62$

116. Winlow W, Pramipexole in restless legs syndrome: an evidence-based review of its effectiveness on clinica outcomes, Core Evid, 2005; 1:35-42.

117. Zhang W, Wang Y, Cong SY, et al., Efficacy and tolerability of pramipexole for the treatment of primary restless leg syndrome: a meta-analysis of randomized placebo-controlled trials, Neuropsychiatr Dis Treat, 2013;9:1035-43.

118. Quilici S, Abrams KR, Nicolas A, et al., Meta-analysis of the efficacy and tolerability of pramipexole versus ropinirole in the treatment of restless legs syndrome, sleep Med 2008:9:715-26.

119. Bogan RK, From bench to bedside: An overview of rotigotine for the treatment of restless legs syndrome, Clin Ther, 2014;36:436-55.

120. Baker WL, White $\mathrm{CM}$, Coleman $\mathrm{Cl}$, Effect of nonergot dopamine agonists on symptoms of restless legs syndrome

121. Zintzaras E, Kitsios GD, Papathanasiou AA, et al., Randomized trials of dopamine agonists in restless legs syndrome: a systematic review, quality assessment, and meta-analysis, Clin Ther, 2010;32:221-37.

122. Scholz H, Trenkwalder $C$, Kohnen R, et al., Dopamine agonists for restless legs syndrome, Cochrane Database Syst Rev, 2011;(3):CD006009.

123. Hornyak M, Trenkwalder C, Kohnen R, Scholz H, Efficacy and safety of dopamine agonists in restless legs syndrome, sleep Med, 2012;13:228-36

124. Wilt TJ, MacDonald R, Ouellette J, et al., Pharmacologic therapy for primary restless legs syndrome: a systematic review and meta-analysis, JAMA Intern Med, 2013;173: 496-505.

125. Hornyak M, Scholz $\mathrm{H}$, Kohnen $\mathrm{R}$, et al, What treatment works best for restless legs syndrome? Meta-analyses of dopaminergic and non-dopaminergic medications, Sleep Med Rev, 2014:18:153-64.

126. Talati R, Phung OJ, Mather J, Coleman $\mathrm{Cl}$, Effect of non-ergo dopamine agonists on health-related quality of life of patients with restless legs syndrome, Ann Pharmacother, 2009;43:813-21.

127. Ondo W, Romanyshyn J, Vuong KD, Lai D, Long-term treatment of restless legs syndrome with dopamine agonists, Arch Neurol, 2004;61:1393-7.

128. Silver N, Allen RP, Senerth J, Earley CJ, A 10-year, longitudina assessment of dopamine agonists and methadone in the treatment of restless legs syndrome, Sleep Med, 
depressive symptoms and restless legs syndrome severity in RLS patients: a multicentre, randomized, placebo-controlled study, J Neurol, 2011;258:1046-54.

133. Driver-Dunckley ED, Noble BN, Hentz JG, et al., Gambling and increased sexual desire with dopaminergic medications in restless legs syndrome, Clin Neuropharmacol, 2007;30: 249-55.

134. García-Borreguero D, Högl B, Ferini-Strambi L, et al, Systematic evaluation of augmentation during treatment with ropinirole in restless legs syndrome (Wilis-Ekbom disease): results from a prospective, multicenter study over 66 weeks Mov Disord, 2012;27:277-83.

35. Ferini-Strambi L, Restless legs syndrome augmentation and pramipexole treatment, Sleep Med, 2002;3 Suppl:S23-5.

136. Silber MH, Girish M, Izurieta R, Pramipexole in the management of restless legs syndrome: an extended study, Sleep, 2003;26:819-21

137. Lipford MC, Silber MH, Long-term use of pramipexole in the management of restless legs syndrome, Sleep Med 2012;13:1280-5.

138. Winkelman JW, Johnston L, Augmentation and tolerance with long-term pramipexole treatment of restless legs syndrome (RLS), Sleep Med, 2004:5:9-14.

139. Beneš H, García-Borreguero D, Ferini-Strambi L, et al., Augmentation in the treatment of restless legs syndrome with transdermal rotigotine, Sleep Med, 2012;13:589-97.

140. García-Borreguero D, Allen RP, Kohnen R, et al., International Restless Legs Syndrome Study Group, Diagnostic standards for dopaminergic augmentation of restless legs syndrome: report from a World Association of Sleep MedicineInternational Restless Legs Syndrome Study Group consensus conference at the Max Planck Institute, Sleep Med 2007;8:520-30

141. Allen RP, Ondo WG, Ball E, et al., Restless legs syndrome (RLS) augmentation associated with dopamine agonist and levodopa usage in a community sample, sleep Med, 2011;12:431-9.

142. Trenkwalder C, Högl B, Benes H, Kohnen R, Augmentation in restless legs syndrome is associated with low ferritin, Sleep Med, 2008:9:572-4.

143. Frauscher B, Gschliesser V, Brandauer E, et al., The severity range of restless legs syndrome (RLS) and augmentation in a prospective patient cohort: association with ferritin levels, Sleep Med, 2009:10:611-5.

144. Nardone R, Ausserer H, Bratti A, et al., Cabergoline reverses cortical hyperexcitability in patients with restless legs syndrome, Acta Neurol Scand, 2006;114:244-9.

145. Gorsler A, Liepert J, Influence of cabergoline on motor excitability in patients with restless legs syndrome, J Clin Neurophysiol, 2007;24:456-60

146. Scalise A, Pittaro-Cadore I, Janes F, et al., Changes of cortical excitability after dopaminergic treatment in restless legs syndrome, Sleep Med, 2010;11:75-81.

147. de la Fuente-Fernández $R$, The powerful pre-treatment effect: placebo responses in restless legs syndrome trials, Eur J Neurol, 2012;19:1305-10.

148. Fulda S, Wetter TC, Where dopamine meets opioids: a metaanalysis of the placebo effect in restless legs syndrome analysis of the placebo effect in restless legs

149. Grewal M, Hawa R, Shapiro C, Treatment of periodic limb movements in sleep with selegiline $\mathrm{HCl}$, Mov Disord, 2002;17:398-401.

150. Babacan-Yildiz G, Gursoy E, Kolukisa M, Celebi A, Restless legs syndrome responsive to rasagiline treatment: a case report, Clin Neuropharmacol, 2012;35:88-9.

151. Kim SW, Shin IS, Kim JM, et al., Bupropion may improve restless legs syndrome: a report of three cases, Clin Neuropharmacol, 2005;28:298-301.

152. Lee JJ, Erdos J, Wilkosz MF, et al., Bupropion as a possible treatment option for restless legs syndrome, Ann Pharmacother, 2009;43:370-4.

153. Bayard M, Bailey B, Acharya D, et al., Bupropion and restless legs syndrome: a random

Fam Med, 2011:24:422-8.

154. Mellick GA, Mellick LB, Management of restless legs syndrome with gabapentin (Neurontin), Sleep, 1996;19:224-6.

155. Adler $\mathrm{CH}$, Treatment of restless legs syndrome with gabapentin, Clin Neuropharmacol, 1997:20:148-51.

156. Happe S, Klösch G, Saletu B, Zeitlhofer J, Treatment of idiopathic restless legs syndrome (RLS) with gabapentin Neurology, 2001; 57:1717-9.

157. Garcia-Borreguero D, Larrosa O, de la Llave Y, et al., Treatmen of restless legs syndrome with gabapentin: a double-blind cross-over study, Neurology, 2002;59:1573-9.

158. Happe S, Sauter C, Klösch G, et al., Gabapentin versus ropinirole in the treatment of idiopathic restless legs syndrome, Neuropsychobiology, 2003;48:82-6.

159. Walters AS, Ondo WG, Kushida CA, et al., XP045 Study Group, Gabapentin enacarbil in restless legs syndrome: a phase $2 b$, 2-week, randomized, double-blind, placebo-controlled tria Clin Neuropharmacol, 2009;32:311-20.

160. Kushida CA, Walters AS, Becker P, et al. XP021 Study Group, A randomized, double-blind, placebo-controlled, crossover study of XP13512/GSK1838262 in the treatment of patients with primary restless legs syndrome, Sleep, 2009:32:159-68.

161. Kushida CA, Becker PM, Ellenbogen AL, et al., XP052 Study Group, Randomized, double-blind, placebo-controlled study of XP13512/GSK1838262 in patients with RLS, Neurology, 2009;72:439-46.

162. Bogan RK, Bornemann MA, Kushida CA, et al., XP060 Study Group, Long-term maintenance treatment of restless legs syndrome with gabapentin enacarbil: a randomized controlled study, Mayo Clin Proc, 2010;85:512-21.

163. Ellenbogen AL, Thein SG, Winslow DH, et al., A 52-week study of gabapentin enacarbil in restless legs syndrome, Clin Neuropharmacol, 2011;34:8-16.

164. Lee DO, Ziman RB, Perkins AT, et al., XP053 Study Group, A randomized, double-blind, placebo-controlled study to assess the efficacy and tolerability of gabapentin enacarb in subjects with restless legs syndrome, J Clin Sleep Med, 2011:7:282-92

165. Winkelman JW, Bogan RK, Schmidt MH, et al., Randomized polysomnography study of gabapentin enacarbil in subjects with restless legs syndrome, Mov Disord, 2011;26:2065-72.

166. Inoue Y, Uchimura N, Kuroda K, et al., Long-term efficacy and safety of gabapentin enacarbil in Japanese restless legs syndrome patients, Prog Neuropsychopharmacol Biol Psychiatry, 2012;36:251-7.

167. Lal R, Ellenbogen A, Chen D, et al., A randomized, doubleblind, placebo-controlled, dose-response study to assess the pharmacokinetics, efficacy, and safety of gabapentin enacarbil in subjects with restless legs syndrome, Clin Neuropharmacol, 2012;35:165-73.

168. Inoue $Y$, Hirata $K$, Uchimura $N$, et al., Gabapentin enacarbil in Japanese patients with restless legs syndrome: a 12-week, andomized, double-blind, placebo-controlled, parallel-group study, Curr Med Res Opin, 2013;29:13-21.

169. VanMeter SA, Kavanagh ST, Warren S, Barrett RW, Dose response of Gabapentin Enacarbil versus placebo in subjects with moderate-to-severe primary restless legs syndrome: an integrated analysis of three 12 -week studies, CNS Drugs, 2012;26:773-80

170. Kume A, Gabapentin enacarbil for the treatment of moderate to severe primary restless legs syndrome (Willis-Ekbom disease): 600 or 1,200 mg dose? Neuropsychiatr Dis Treat 2014;10:249-62.

171. Sun $Y$, van Valkenhoef $G$, Morel T, A mixed treatment comparison of gabapentin enacarbil, pramipexole, ropinirole and rotigotine in moderate-to-severe restless legs syndrome, Curr Med Res Opin, 2014;30:2267-78.

172. Sommer M, Bachmann CG, Liebetanz KM, et al., Pregabalin in restless legs syndrome with and without neuropathic pain, Acta Neurol Scand, 2007;115:347-50.

173. Garcia-Borreguero D, Larrosa O, Williams AM, et al., Treatment of restless legs syndrome with pregabalin: a double-blind, placebo-controlled study, Neurology, 2010;74:1897-904.

174. Allen R, Chen C, Soaita A, et al., A randomized, double-blind, 6-week, dose-ranging study of pregabalin in patients with restless legs syndrome, Sleep Med, 2010;11:512-9.

175. Garcia-Borreguero D, Patrick J, DuBrava S, et al., Pregabalin versus pramipexole: effects on sleep disturbance in restless legs syndrome, Sleep, 2014;37:635-43.

176. Allen RP, Chen C, Garcia-Borreguero D, et al., Comparison of pregabalin with pramipexole for restless legs syndrome, $N$ Eng/ J Med, 2014;370:621-31.

177. Eisensehr I, Ehrenberg BL, Rogge Solti S, Noachtar S, Treatment of idiopathic restless legs syndrome (RLS) with slow-release valproic acid compared with slow-release levodopa/benserazide, J Neurol, 2004:251:579-83.

178. Lundvall O, Abom PE, Holm R, Carbamazepine in restless legs: a controlled pilot study, Eur I Clin Pharmacol, 1983;25:323-4.

179. Telstad W, Sørensen O, Larsen S, et al., Treatment of the restless legs syndrome with carbamazepine: a double blind study, Br Med I (Clin Res Ed), 1984;288:444-6.

180. Larsen S, Telstad W, Sørensen O, et al., Carbamazepine therapy in restless legs: discrimination between responders and non-responders, Acta Med Scand, 1985;218:223-7.

181. Pérez Bravo A, Topiramate use as treatment in restless legs syndrome, Actas ESP Psiquiatr, 2004;32:132-7.

182. Youssef EA, Wagner ML, Martinez JO, Hening W, Pilot trial of lamotrigine in the restless legs syndrome, Sleep Med 2005;6:89.

183. Della Marca G, Vollono C, Mariotti P, et al., Levetiracetam can be effective in the treatment of restless legs syndrome with periodic limb movements in sleep: report of two cases, J Neurol Neurosurg Psychiatry, 2006;77:566-7.

184. Lasaosa SS, Pellicer PL, Fernández LG, Levetiracetam and restless leg syndrome, Neurologia, 2008;23:395-6.

185. Jimenez-Trevino L, Oxcarbazepine treatment of restless legs syndrome: three case reports, Clin Neuropharmacol, 2009;32:169-70.

186. Trzepacz PT, Violette EJ, Sateia MJ, Response to opioids in three patients with restless legs syndrome, Am J Psychiatry 1984;141:993-5

187. Gillman MA, Sandyk R, Opioids, dopamine, and restless legs syndrome, Am J Psychiatry, 1985;142:662.

188. Sandyk R, Gillman MA, The opioid system in the restless leg and nocturnal myoclonus syndromes, Sleep, 1986;9:370-1.

189. Sandyk R, Bamford CR, Gillman MA, Opiates in the restless legs syndrome, Int I Neurosci, 1987;36:99-104.

190. Kavey N, Walters AS, Hening W, Gidro-Frank S, Opioid treatment of periodic movements in sleep in patients without restless legs, Neuropeptides, 1988;11:181-4.

191. Vahedi H, Küchle M, Trenkwalder C, Krenz CJ, Peridural morphine administration in restless legs status, Anasthesio Intensivmed Notfallmed Schmerzther, 1994;29:368-70.

192. Jakobsson B, Ruuth K, Successful treatment of restless legs syndrome with an implanted pump for intrathecal drug delivery, Acta Anaesthesiol Scand, 2002;46:114-7.

193. Lindvall PK, Ruuth K, Jakobsson B, Nilsson SK, Intrathecal morphine infusion a possible treatment in restless legs, Lakartidningen, 2007;104:2250-2.

194. Ross DA, Narus MS, Nutt JG, Control of medically refractory restless legs syndrome with intrathecal morphine: case

report, Neurosurgery, 2008;62:E263; discussion E263.

95. Hornyak M, Kaube $\mathrm{H}$, Long-term treatment of a patient with severe restless legs syndrom

196. Lindvall P, Hariz GM, Blomstedt P. Overall self-perceived health in restless legs treated with intrathecal morphine, Acta Neurol Scand, 2013:127:268-73.

197. Scherbaum N Stüper B, Bonnet U, Gastpar M, Transient restless legs-like syndrome as a complication of opiate withdrawal, Pharmacopsychiatry, 2003;36:70-2.

198. Winkelmann J, Schadrack J, Wetter TC, et al., Opioid and dopamine antagonist drug challenges in untreated restless legs syndrome patients, sleep Med, 2001;2:57-61.

199. Lauerma H, Markkula J, Treatment of restless legs syndrom with tramadol: an open study, J Clin Psychiatry, 1999;60: 241-4.

200. Earley CJ, Allen RP, Restless legs syndrome augmentation associated with tramadol, Sleep Med, 2006;7:592-3.

201. Vetrugno R, La Morgia C, D'Angelo R, et al., Augmentation of restless legs syndrome with

202. Walters AS, Wagner ML, Hening WA, et al., Successful treatment of the idiopathic restless legs syndrome in a randomized double-blind trial of oxycodone versus placebo Sleep, 1993;16:327-32.

203. Trenkwalder C, Beneš H, Grote L, et al., RELOXYN Study Group, Prolonged release oxycodone-naloxone for treatment of severe restless legs syndrome after failure of previous treatment. a double-blind, randomised, placebocontrolled trial with an open-label extension, Lancet Neurol, 2013;12:1141-50.

204. Ondo WG, Methadone for refractory restless legs syndrome, Mov Disord, 2005;20:345-8.

205. Walters AS, Winkelmann J, Trenkwalder C, et al., Long-term follow-up on restless legs syndrome patients treated with opioids, Mov Disord, 2001;16:1105-9.

206. Boghen D, Successful treatment of restless legs with clonazepam, Ann Neurol, 1980;8:341.

207. Montagna P, Sassoli de Bianchi L, Zucconi M, et al., Clonazepam and vibration in restless legs syndrome, $A$ Acta Neurol Scand, 1984:69:428-30.

208. Boghen $D$, Lamothe $L$, Elie $R$, et al. The treatment of the restless legs syndrome with clonazepam: a prospective controlled study, Can J Neurol Sci, 1986;13:245-7.

209. Peled R, Lavie P, Double-blind evaluation of clonazepam on periodic leg movements in sleep, J Neurol Neurosurg Psychiatry, 1987;50:1679-81

210. Horiguchi J, Inami Y, Sasaki A, et al., Periodic leg movements in sleep with restless legs syndrome: effect of clonazepam treatment, Jpn J Psychiatry Neurol, 1992;46:727-32.

211. Saletu M, Anderer P, Saletu-Zyhlarz G, et al., Restless legs syndrome (RLS) and periodic limb movement disorder (PLMD): acute placebo-controlled sleep laboratory studies with clonazepam, Eur Neuropsychopharmacol, 2001;11:153-61.

212. Tollefson G, Erdman C, Triazolam in the restless legs syndrome, J Clin Psychopharmacol, 1985;5:361-2.

213. Doghramii K, Browman CP, Gaddy JR, Walsh JK, Triazolam diminishes daytime sleepiness and sleep fragmentation in patients with periodic leg movements in sleep, $J$ Clin in patients with periodic leg movem

214. Bonnet MH, Arand DL, Chronic use of triazolam in patients with periodic leg movements, fragmented sleep and daytime sleepiness, Aging (Milano), 1991; 3:313-24.

215. Scharf MB, Brown L, Hirschowitz J, Possible efficacy of alprazolam in restless leg syndrome, Hillside J Clin Psychiatry, 1986;8:214-23.

216. Bezerra ML, Martínez JV, Zolpidem in restless legs syndrome, Eur Neurol, 2002;48:180-1.

217. Davis BJ, Rajput A, Rajput ML, et al., A randomized, double-blind placebo-controlled trial of iron in restless legs syndrome, Eur Neurol, 2000:43:70-5.

218. Wang J, O'Reilly B, Venkataraman R, et al., Efficacy of oral iron in patients with restless legs syndrome and a low-normal ferritin: A randomized, double-blind, placebo-controlled study Sleep Med, 2009:10:973-5.

219. Mohri I, Kato-Nishimura K, Kagitani-Shimono K, et al., Evaluation of oral iron treatment in pediatric restless legs syndrome (RLS), Sleep Med, 2012:13:429-32.

220. Amos LB, Grekowicz ML, Kuhn EM, et al., Treatment of pediatric restless legs syndrome, Clin Pediatr (Phila), 2014;53:331-6.

221. Lee CS, Lee SD, Kang SH, et al., Comparison of the efficacies of oral iron and pramipexole for the treatment of restless legs syndrome patients with low serum ferritin,. Eur I Neurol, 2014;21:260-6.

222. Earley CJ, Heckler D, Allen RP, The treatment of restless legs syndrome with intravenous iron dextran, Sleep Med 2004;5:231-5.

223. Grote L, Leissner L, Hedner J, Ulfberg J, A randomized, doubleblind, placebo controlled, multi-center study of intravenous iron sucrose and placebo in the treatment of restless legs 
227. Hornyak M, Scholz H, Kiemen A, Kassubek J, Investigating the response to intravenous iron in restless legs syndrome: an observational study, Sleep Med, 2012:13:732-5.

228. Cho YW, Allen RP, Earley CJ, Lower molecular weight intravenous iron dextran for restless legs syndrome, Sleep Med, 2013;14:274-7.

229. Grim K, Lee B, Sung AY, Kotagal S, Treatment of childhoodonset restless legs syndrome and periodic limb movement disorder using intravenous iron sucrose, Sleep Med, 2013:14:1100-4.

230. Rotenberg JS, Canard K, Difazio M, Successful treatment of recalcitrant restless legs syndrome with botulinum tox type-A, J Clin Sleep Med, 2006;2:275-8.

231. Ghorayeb I, Burbaud $P$, Failure of botulinum toxin $A$ to relieve restless legs syndrome, Sleep Med, 2009;10:394-5.

232. Agarwal P, Sia C, Vaish N, Roy-Faderman I, Pilot trial of onabotulinumtoxina (Botox) in moderate to severe restless legs syndrome, Int J Neurosci, 2011;121:622-5.

233. Nahab FB, Peckham EL, Hallett M, Double-blind, placebocontrolled, pilot trial of botulinum toxin A in restless legs syndrome, Neurology, 2008;71:950-1.

234. Ghorayeb I, Bénard A, Vivot A, et al., A phase II, open-label, non-comparative study of Botulinum toxin in restless legs non-comparative study of Botulinum
syndrome, Sleep Med, 2012;13:1313-6.

235. Hornyak M, Rupp A, Riemann D, et al., Low-dose hydrocortisone in the evening modulates symptom severity in restless legs syndrome, Neurology, 2008;70:1620-2.

236. van Dijk JG, Bollen EL, Slootweg J, et al., No difference in efficacy of hydroquinone and placebo in restless leg syndrome, Ned Tijdschr Geneeskd, 1991;135:759-63.

237. Cuellar NG, Ratcliffe SJ, Does valerian improve sleepiness and symptom severity in people with restless legs syndrome? Altern Ther Health Med, 2009;15:22-8.

238. Oksenberg A, Alleviation of severe restless legs syndrome (RLS) symptoms by cigarette smoking, I Clin Sleep Med, 2010;6:489-90.

239. Romigi A, Vitrani G, Improvement of restless legs syndrome by varenicline as antismoking treatment, J Clin Sleep Med 2013:9:1089-90

240. Alpert CC, Tobin DP, Dierdorf SF, Physostigmine for the acute treatment of restless legs syndrome, Anesth Analg, 2005;101:726-7.

241. Peacock J, Mishra G, Roy RC, Physostigmine and restless legs syndrome Anesthesiology, 2012:117:1144-5.

242. Popkin RJ, Orphenadrine citrate (Norflex) for the treatment of "restless legs" and related syndromes, J Am Geriatr Soc, 1971;19:76-9.

243. Di Fabio R, Casali C, Vadalà R, Pierelli F, Hydroxyzine hydrochloride in familial restless legs syndrome, Can I Neurol Sci, 2010;37:406-7.

244. Zoe A, Wagner ML, Walters AS, High-dose clonidine in a case of restless legs syndrome, Ann Pharmacother, 1994;28:878-81.

245. Bamford CR, Sandyk R, Failure of clonidine to ameliorate the symptoms of restless legs syndrome, Sleep, 1987:10:398-9.

246. Sandyk R, lacono RP, Bamford CR, Spinal cord mechanisms in amitriptyline responsive restless legs syndrome

in Parkinson's disease, Int J Neurosci, 1988:38:121-4.
247. Dimmitt SB, Riley GJ, Selective serotonin receptor uptake inhibitors can reduce restless legs symptoms, Arch Intern Med, 2000;160:712.

248. Kapur $\mathrm{N}$, Friedman R, Oral ketamine: a promising treatment for restless legs syndrome, Anesth Analg, 2002;94. $1558-9$.

249. Sandyk R, Melanocyte stimulating hormone (MSH) in the restless-legs syndrome, Int J Neurosci, 1989;46:197-9.

250. Ayres S Jr, Mihan R, Leg cramps (systremma) and "restless egs" syndrome: response to vitamin E (tocopherol), Calif Med, 1969;111:87-91

251. Mangan $D, A$ case report of niacin in the treatment of restless legs syndrome, Med Hypotheses, 2009;73:1072

252. Wali S, Shukr A, Boudal A, et al., The effect of vitamin D supplements on the severity of restless legs syndrome Sleep Breath, 2015, 19: 579-83.

253. Hornyak M, Voderholzer U, Hohagen F, et al., Magnesium therapy for periodic leg movements-related insomnia and restless legs syndrome: an open pilot study Sleep, 1998:21:501-5.

254. Bartell S, Zallek S, Intravenous magnesium sulfate may relieve restless legs syndrome in pregnancy, $J$ Clin Sleep Med, 2006:2:187-8.

255. Rahimdel AG, Ayatollahi P, Zeinali A, et al., The effect of selenium administration on restless leg syndrome treatment Iran Red Crescent Med I, 2012:14:14-9.

256. Ekbom KA, Restless legs, Acta Med Suppl, 1945;158:5-123.

57. Ulfberg J, Treatment of restless legs syndrome with a nitroglycerin patch, Sleep Med, 2012;13:1326.

258. Lin Z, How to treat restless leg syndrome with traditional Chinese medicine? J Tradit Chin Med, 2003;23:306-7.

259. Yan X, Wang WD, Walters AS, et al., Traditional Chinese medicine herbal preparations in restless legs syndrome (RLS) treatment: a review and probable first description of RLS in 1529, Sleep Med Rev, 2012;16:509-18

260. Shinno H, Yamanaka M, Ishikawa I, et al., Successfu treatment of restless legs syndrome with the herbal prescription yokukansan, Prog Neuropsychopharmacol Biol Psychiatry, 2010;34:252-3.

261. Pereira IC Ir, Pradella-Hallinan M, Alves RC, Saint John's wort an herbal inducer of the cytochrome P4503A4 isoform, may alleviate symptoms of Willis-Ekbom's disease, Clinics (SaO Paulo), 2013;68:469-74.

262. Decerce J, Smith LF, Gonzalez W, Sussman NM, Effectiveness and tolerability of istradefylline for the treatment of restless egs syndrome: an exploratory study in five female patients, Curr Ther Res Clin Exp, 2007;68:349-59.

263. Whittom S, Dumont M, Petit D, et al., Effects of melatonin and bright light administration on motor and sensory symptoms of RLS, Sleep Med, 2010;11:351-5.

264. Cui Y, Wang Y, Liu Z, Acupuncture for restless legs syndrome, Cochrane Database Syst Rev, 2008 Oct 8;(4):CD006457.

265. WU YH, Sun CL, Wu D, et al., Observation on therapeutic effect of acupuncture on restless legs syndrome, Zhongguo Zhen Jiu, 2008;28:27-9.
266. Cripps MG, Acupuncture for restless legs syndrome in patients previously treated with dopaminergic drugs, Acupunct Med, 2011;29:240-1.

267. Aukerman MM, Aukerman D, Bayard M, et al., Exercise and restless legs syndrome: a randomized controlled trial, J Am Board Fam Med, 2006:19:487-93.

268. Innes KE, Selfe TK, Agarwal P, et al., Efficacy of an eight-week yoga intervention on symptoms of restless legs syndrome (RLS): a pilot study, J Altern Complement Med, 2013; 19:527-35.

269. Dinkins EM, Stevens-Lapsley J, Management of symptoms of restless legs syndrome with use of a traction straight leg raise: a preliminary case series, Man Ther, 2013;18:299-302.

270. Altunrende B, Yildiz S, Cevik A, Yildiz N, Repetitive transcrania magnetic stimulation in restless legs syndrome: preliminary results, Neurol SCi, 2014;35:1083-8

271. Koo YS, Kim SM, Lee C, et al., Transcranial direct current stimulation on primary sensorimotor area has no effect in patients with drug-naive restless legs syndrome: a proof-ofconcept clinical trial, Sleep Med, 2015; 16:280-7.

272. Vignatelli L, Billiard M, Clarenbach P, et al., EFNS Task Force, EFNS guidelines on management of restless legs syndrome and periodic limb movement disorder in sleep, Eur J Neurol, 2006;13:1049-65.

273. Hening WA, Current guidelines and standards of practice for restless legs syndrome, Am 」 Med, 2007:120 (1 Suppl. 1): S22-7.

274. Trenkwalder $\mathrm{C}$, Hening WA, Montagna P, et al., Treatment of restless legs syndrome: an evidence-based review an implications for clinical practice, Mov Disord, 2008;23: 2267-302.

275. Garcia-Borreguero D, Ferini-Strambi L, Kohnen R, et al., European Federation of Neurological Societies, European Neurological Society, European Sleep Research Society, European guidelines on management of restless legs syndrome: report of a joint task force by the European Federation of Neurological Societies, the European Neurological Society and the European Sleep Research Society, Eur I Neurol, 2012:19:1385-96.

276. Aurora RN, Kristo DA, Bista SR, et al., American Academy of Sleep Medicine, The treatment of restless legs syndrome and periodic limb movement disorder in adults-an update for 2012: practice parameters with an evidence-based systematic review and meta-analyses-an American Academy of Sleep Medicine Clinical Practice Guideline, Sleep, Academy of Sleep
2012:35:1039-62.

277. Garcia-Borreguero D, Kohnen R, Silber MH, et al., The longterm treatment of restless legs syndrome/Willis-Ekbom disease: evidence-based guidelines and clinical consensus best practice guidance- - a report from the International Restless Legs Syndrome Study Group, Sleep Med. 2013;14:675-84.

278. Silber MH, Becker PM, Earley C, et al., Medical Advisory Board of the Willis-Ekbom Disease Foundation, Willis-Ekbom Disease Foundation revised consensus statement on the management of restless legs syndrome, Mayo Clin Proc, 2013;88:977-86. 